\title{
Biogenic Synthesis of Nanoparticles and Potential Applications: An Eco- Friendly Approach
}

\section{Arun G. Ingale* and A. N. Chaudhari}

Department of Biotechnology, School of Life Sciences, North Maharashtra University, Jalgaon-425001, India

\begin{abstract}
The uprising in materials science has been hosted by previous few decades. There has been a substantial research interest in the area of using particulate systems to accomplish various approaches. The conception or synthesis of material with nanometer-scale precision (nanoparticles), by means of material science, is nanotechnology. Nanoparticles are defined as particulate dispersal or solid particles, with a size in the range of 1-100 nm.

This review intends to present biosynthesis and application of nanoparticles in minutiae. Here, we discussed different synthesis methods, i.e. chemical, physical and biogenic synthesis of nanoparticles. The potential come together between nanotechnology and biological science is enormous. Realistic biologics depends on units that have nanoscale dimensions (proteins, viruses, molecular motors, extra cellular matrix). Our major dictum is to focus the various facet of synthesis of nanoparticles, characterization, and its imperative application by giving accent on biogenic synthesis of nanoparticles.
\end{abstract}

Keywords: Nanoparticles; Biosynthesis; Potential application

\section{Introduction}

Nanotechnology is facilitating technology that deals with nanometer sized items [1]. The exercise of nanomaterials in biotechnology unites the fields of biology and material science. Nanoparticles put forward an essentially useful platform, demonstrating unique properties with potentially wide-ranging application [2]. Owing to the many rewards over non-biological systems, several research groups have oppressed the use of biological systems for the synthesis of nanoparticles. The exclusive properties and usefulness of nanoparticles arise from a variety of aspects, including the similar size of nanoparticles and biomolecules, such as proteins and polynucleic acids [3]. The nanoparticles synthesized by means of biogenic approach present good polydispersity, dimensions and stability. The nanoparticles are synthesised through physical, chemical and biological methods [4]. The physical and chemical methods are extremely pricey [5]. The biological methods of nanoparticles synthesis would assist to remove ruthless processing conditions, by allowing the synthesis at physiological $\mathrm{pH}$, temperature, pressure, and at the same time, at negligible cost. Huge number of micro organisms have been found competent of synthesizing inorganic nanoparticles composite, either intra or extracellularly. Due to implausible properties, nanoparticles have turned into noteworthy in many fields in the recent years, such as energy, health care, environment, agriculture, etc. The preparation of nanoparticles is established either by (i) Nanoparticles synthesis, or by (ii) Processing of nanomaterials into nanostructure particles [6].

In this review, we have discussed general approaches to the synthesis of nanoparticles by various methods and applications. The research and product developments in the vicinity of nanotechnology have progressively increased, chiefly due to new and valuable properties of nanomaterials. New nanomaterials, an inherent part of nanotechnological developments, allow on the one hand, new products and solutions [7]. The probable applications of nanotechnology and nanoparticles in different fields have reformed the sciences and industries that are discussed here.

\section{Synthesis of Nanoparticles}

\section{Chemical synthesis}

Chemical method of synthesis is valuable as it takes tiny period of time for synthesis of large quantity of nanoparticles. Nevertheless, in this method, capping agents are necessary for size stabilization of the nanoparticles. Nanoparticles have been synthesized, most recurrently by three chemical techniques:

- Dispersion of preformed polymers

- Polymerization of monomers

- Ionic gelation or coacervation of hydrophilic polymers

Dispersion of preformed polymers: A number of methods have been recommended to prepare nanoparticles from PLA (polylactic acid), PLG (poly-D-L-glycolide), PLGA (poly-D-L-lactide-coglycolide) and PCA (Poly- $\varepsilon$-caprolactone), by dispersing the preformed polymers $[8,9]$.

Polymerization of monomers: Nanoparticles can moreover be prepared by polymerization of monomers. Polymeric nanoparticles achieved from copolymers of methacrylic acid, acrylic esters or metacrylics, have been extensively been used [10].

Ionic gelation or coacervation of hydrophilic polymers: During this method, ionic gelation of the material experienced transition from liquid to gel due to ionic interactions. Chitosan, gelatine and sodium alginate is utilized for preparation of hydrophilic nanoparticles by ionic gelation [11]. Nanoparticles can be prepared from a wide range of materials such as proteins, polysaccharides and synthetic polymers, etc. (Figure 1); usually used reductants are borohydride, citrate, ascorbate and elemental hydrogen $[12,13]$. Furthermore, chemicals reagents used

*Corresponding author: Arun G. Ingale, Department of Biotechnology, School of Life Sciences, North Maharashtra University, Jalgaon-425001, India, E-mail: agibiotech@gmail.com

Received January 11, 2013; Accepted February 04, 2013; Published February 08,2013

Citation: Ingale AG, Chaudhari AN (2013) Biogenic Synthesis of Nanoparticles and Potential Applications: An Eco-Friendly Approach. J Nanomed Nanotechol 4 165. doi:10.4172/2157-7439.1000165

Copyright: @ 2013 Ingale AG, et al. This is an open-access article distributed under the terms of the Creative Commons Attribution License, which permits unrestricted use, distribution, and reproduction in any medium, provided the original author and source are credited. 
<smiles>CC(C)C(=O)OC(C)C1CC1(C)O</smiles>

Structure of PLA<smiles>CCC(C)C(=O)OC(C)(C)CC(=O)OC(C)(C)C</smiles>

Structure of PGLA<smiles>C=C(C)C(=O)CCCCCC(C)(C)C</smiles>

Structure of PCA

Figure 1: Structure of different polymers used for nanoparticle synthesis.

normally for nanoparticles synthesis and stabilization are toxic and lead to byproducts that are not ecofriendly [14].

\section{Physical synthesis}

The above method is hardly ever used methods in physical processes; metal nanoparticles are synthesized by evaporation-condensation, which might be carried out using a tube furnace at atmospheric pressure. The starting material inside a boat centered at the furnace is vaporized into a carrier gas. Nanoparticles of different materials such as $\mathrm{Ag}, \mathrm{Au}, \mathrm{PbS}$ and fullerene have formerly been produced using the evaporation/condensation techniques [15-18]. Initially, the design and description of two-dimensional arrays of colloidal Au particles are existing, and later Grabar reported a new loom to develop $\mathrm{Au}$ colloid through surface-enhanced Raman scattering (SERS) substrates. $\mathrm{Au}$ colloid monolayers possess a set of features that make them very attractive for both basic and applied uses, including uniform roughness, high stability, and biocompatibility [19]. Recently Mirza and Shamshad [20] investigated the gold nanoparticles (Au NPs) functionalized with an anticancer drug, doxorubicin. Their study laid the basis of a linking methodology via hybrid multi drug, and receptor labelled NPs might be developed, which may provide an alternative design for nanosized drug-delivery system.

\section{Biological synthesis}

Our key purpose is to highlight on the biological synthesis of nanoparticles, because of its easiness of rapid synthesis, controlled toxicity, controlling on size characteristics, reasonable, and eco friendly approach. A sum of natural sources is there for nanoparticle synthesis, together with plants, fungi, yeast, bacteria, etc. Additionally, the unicellular and multicultural organisms are able to synthesise intracellular and extra cellular inorganic nanoparticles. The various sources of nanoparticles synthesis are enlisted in table 1 .

Nanoparticle synthesis by plant extracts: Make use of plants in the synthesis of nanoparticles has drawn more interest of workers because it provides single step biosynthesis process. Plants tender a superior option for synthesis of nanoparticle, as the protocols involving plant sources are free from toxicants; furthermore, natural capping agents are readily supplied by the plants (Figure 2 ).

The production of gold and silver nanoparticles using Geranium extract [21], Aloe vera plant extracts [22], sundried Cinnamomum camphora and Azadiracta indica leaf extract has been explained [2325]

Inexpensive reduction of silver and gold ions present concurrently in solution, during exposure to plant leaf extract, generates bimetallic silver and gold shell nanoparticles. The information is also available for the synthesis of silver nanoparticles, using Plumeria rubra plant latex [25]. Nanoparticle synthesis furthermore carried out using Szyygium aromaticum bud extract, Murraya koenigii leaf extract. This synthesis is owing to the natural reducing agent eugenol and could be carbazoles present in the extracts correspondingly [26,27]. Biosynthesis of gold nanoparticles utilizing the leaf extract of Mirabilis jalapa was explicated [28].

Nanoparticle synthesis by bacteria: In previous years, synthesis of nanoparticles using bacteria has enlarged comprehensively due to its immense application. Bacillus species has depicted to synthesise metal nanoparticles, researchers showed the ability of bacteria to decrease silver and fabrication of extracellularly, consistently circulated nanoparticles, ranging from 10-20 nm size [58]. The Silver producing bacteria isolated from the silver mines exhibit the silver nanoparticles accumulated in the periplasmic space of Pseudomonas stutzeri AG259 [59]. Bacteria are also used to synthesize gold nanoparticles. Sharma et al. [60] reported that whole cells of a novel strain of Marinobacter pelagius are applicable for stable, monodisperse gold nanoparticle formation. Prasad et al. [61] has been reported use of Lactobacillus strains to synthesise the titanium nanoparticles. The understanding of natural processes will apparently help in the discovery of entirely new and unexplored methodology of metal nanoparticle synthesis.

Nanoparticle synthesis by fungi: Biological production of nanoparticles by fungi is determined nowadays because of their reception towards toxicity, higher bioaccumulation, comparatively economic, effortless synthesis method and simple downstream processing and biomass handling.

Extracellular biosynthesis of silver nanoparticles by Aspergillus niger [41], Fusarium solani [44] and Aspergillus oryzae are reported to produce silver nanocrystals [42]. The Pleurotus sajor caju was also used for synthesis of nanoparticles extracellularly [45]. The spherical nanoparticle can be synthesized by Trichoderma viride [46]. Prologue of silver ions to Fusarium oxysporum leads to synthesis of stable $\mathrm{Ag}$ hydrosols [62]. Phoma glomerata has been traced to produce silver nanoparticles, and its efficiency against E.coli, S. aureus and $P$. aeruginosa has been assessed [63]. The genus Penicillium seems to have a superior contender for the silver nanoparticle synthesis, where production proceeds via extracellular mechanism [64].

Nanoparticle synthesis by yeast: The extracellular synthesis of nanoparticles in huge quantities, with straightforward downstream processing, has been reported by Kowshik et al. [48]. This group has been involved in isolation of silver tolerant yeast strain MKY3, by inoculating with aqueous silver nitrate. The formation of $2-5 \mathrm{~nm}$ silver nanoparticles takes place in the forced ecological conditions. The synthesis of cadmium nanoparticles by using Candida glabrata and Schizosaccharomyce pombe has been reported by Dameron et al. [49]. The silver and gold nanoparticles biosynthesis was also investigated by Mourato et al. [50], using an extremophilic yeast strain isolated from acid mine drainage. The marine yeast Rhodosporidium diobovatum has been explored for intracellular synthesis of stable lead sulfide nanoparticles [51].

Nanoparticle synthesis by biological particles: Biological particles 
Citation: Ingale AG, Chaudhari AN (2013) Biogenic Synthesis of Nanoparticles and Potential Applications: An Eco-Friendly Approach. J Nanomed Nanotechol 4: 165. doi:10.4172/2157-7439.1000165

Page 3 of 7

\begin{tabular}{|c|c|c|}
\hline Source & Types and size of NPs (nm) & References \\
\hline \multicolumn{3}{|l|}{ Plant } \\
\hline Azadirachta indica & Ag,Au 50/100 & Shankar et al. [21] \\
\hline Aloe vera & Au $50 / 350$ & Chandran et al. [22] \\
\hline Cinnamomum camphora & $\operatorname{Ag} 50$ & Huang et al. [23] \\
\hline Szygium aromaticum & Ag,Au --- & Kalpana devi et al. [29] \\
\hline Murraya koenigii & $\mathrm{Ag}$ & Christensen et al. [27] \\
\hline Plumeria rubra & $\mathrm{Ag}$ & Patil et al. [25] \\
\hline Citrus aurantium & $\mathrm{Ag}$ & Pala et al. 30] \\
\hline Geranium leaf plant extract & $\operatorname{Ag} 16 / 40$ & Shankar et al. [21] \\
\hline Jatropha curcas & $\mathrm{Ag}>20$ & Pala et al. [30] \\
\hline Tridax procumbens & $\mathrm{Ag}>20$ & Pala et al. [30] \\
\hline Hibiscus rosa sinensis & $\operatorname{Ag} 13 / 20$ & Daizy [31] \\
\hline \multicolumn{3}{|l|}{ Bacteria } \\
\hline Bacillus cereus & $\operatorname{Ag} 5$ & Ganesh Babu and Gunasekaran [32] \\
\hline Bacillus thuringiensis & $\operatorname{Ag~10/20~}$ & Jain et al. [33] \\
\hline Escherichia coli & $\operatorname{Ag~30/50~}$ & Gurunathan et al. [34] \\
\hline Escherichia coli & Cds--- & Sweeney et al. [35] \\
\hline Lactobacillus strains & Ag,Au 15/40 & Sintubin et al. [36] \\
\hline Pseudomonas stutzeri & $\mathrm{Ag}>200$ & Klaus et al. [37] \\
\hline Corynebacterium & $\operatorname{Ag} 5 / 15$ & Zhang et al. [38] \\
\hline Staphylococcus aureus & Ag 150/180 & Nanda and Saravanan [39] \\
\hline Ureibacillus thermosphaericus & $\operatorname{Ag} 1 / 100$ & Juibari et al. [40] \\
\hline \multicolumn{3}{|l|}{ Fungi } \\
\hline Aspergillus niger & $\operatorname{Ag} 20$ & Gade et al. [41] \\
\hline Aspergillus oryzae & Ag 5-50 & Binupriya et al. [42] \\
\hline Fusarium oxysporum & $\operatorname{Ag} 1 / 5$ & Duran et al. [43] \\
\hline Fusarium solani & $\operatorname{Ag} 5 / 35$ & Ingle et al. [44] \\
\hline Pleurotus sajor-caju & $\operatorname{Ag} 5 / 50$ & Nithya and Ragunathan [45] \\
\hline Trichoderma viride & $\operatorname{Ag} 10 / 40$ & Thakkar et al. [46] \\
\hline Klebsiella pneumoniae & Se $100 / 400$ & Fesharaki et al. [47] \\
\hline \multicolumn{3}{|l|}{ Yeast } \\
\hline Silver-tolerant strain MKY3 & $\operatorname{Ag} 2 / 20$ & Kowshik et al. [48] \\
\hline Candida glabrata & CdS 50/150 & Dameron et al. [49] \\
\hline Schizosaccharomyce pombe & CdS 50/150 & Dameron et al. [49] \\
\hline Extremophillic yeast & $\mathrm{Ag}$ & Mourato et al. [50] \\
\hline Rhodospiridium dibovatum & $\mathrm{PbS}$ & Seshadri et al. [51] \\
\hline \multicolumn{3}{|l|}{ Biomolecules } \\
\hline DNA & $\mathrm{Au} / \mathrm{CdS}$ & Mahtab et al. and Shaiu et al. [52] [53] \\
\hline Proteins & $\mathrm{Au}$ & Safer et al. and Hainfeld and Furuya [54] [55] \\
\hline Immunoglobulins, serum albumins & $\mathrm{Au}$ & Shenton et al. and Beesley [56] [57] \\
\hline
\end{tabular}

Table 1: Altered sources of nanoparticles synthesis.

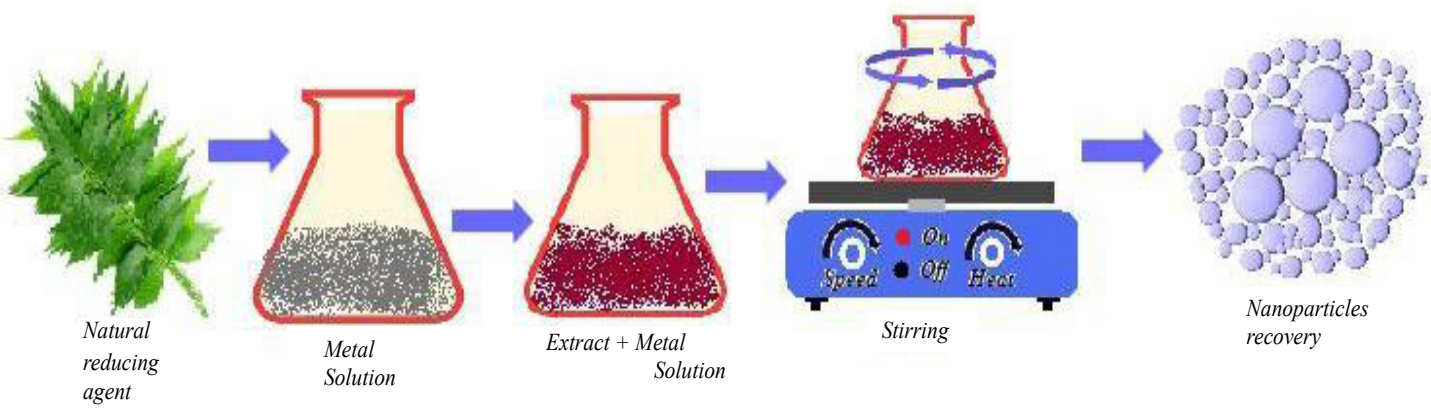

Figure 2: Synthesis of nanoparticles from plant extract.

like viruses, proteins, peptides and enzymes could be exploited for biosynthesis of nanoparticles (Figure 3). For the mineralization of inorganic materials, Cowpea chlorotic mottle virus and cowpea mosaic virus have been employed $[65,66]$. Tobacco mosaic virus helps for the mineralization of sulphide and crystalline nanowires [67]. Peptides are competent of nucleating nanocrystal growth, and have been recognized from combinatorial screens and demonstrated on the surface of M13 bacteriophage [68]. 


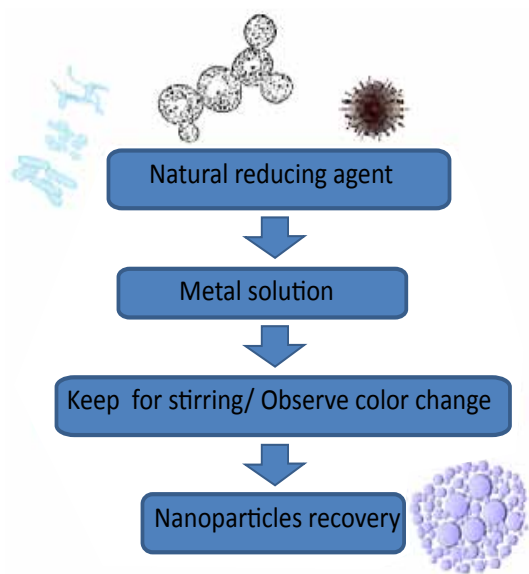

Figure 3: Schematics of synthesis of nanoparticles from various sources.

\section{Characterization}

Characterization of nanoparticles is significant to appreciate and control nanoparticles synthesis and applications. Nanoparticles characterization is executed using a range of diverse techniques like scanning and transmission electron microscopy (SEM, TEM), Fourier transform infrared spectroscopy (FTIR), X-ray photoelectron spectroscopy (XPS), atomic force microscopy (AFM), dynamic light scattering (DLS), powder X-ray diffractometry (XRD), and UVVis spectroscopy. These techniques are helpful to resolve diverse parameters such as particle size, shape, crystallinity, fractal dimensions, pore size and surface area. Additionally, orientation, intercalation and dispersion of nanoparticles and nanotubes in nanocomposite materials could be decided by these techniques. The morphology and particle size possibly will be determined by TEM, SEM and AFM. The improvement of AFM over conventional microscopes such as SEM and TEM is that AFM technique measures 3D images, so that particle height and volume can be intended. Moreover, dynamic light scattering is applied for determination of particles size distribution. Furthermore, X-ray diffraction is exercise for the determination of crystallinity, while UVVis spectroscopy is utilized to confirm sample formation by exhibiting the Plasmon resonance [69-78].

\section{Applications}

There are widespread applications of nanoparticles such as pharmaceuticals, cosmetics, food and beverages, agriculture, surface coating, polymers, etc. (Figure 4); few of them are discussed here.

\section{Nanoparticles as potent antimicrobial agent}

The silver nanoparticles synthesised using an endophytic fungus, Pestalotia sp., isolated from leaves of Syzygium cumini has antibacterial activity against human pathogens, i.e. S. aureus and S. typhi [79]. Silver nanoparticles showed powerful bactericidal potential against both Gram-positive and Gram-negative bacteria. Numbers of silver nanoparticles are used against pathogenic bacteria. The bactericidal prospective of silver nanoparticles against the MDR bacteria are also investigated $[80,81]$.

\section{Nanoparticles in electrochemical sensors and biosensors}

A set of forms of nanoparticles such as oxide, metal and semiconductor nanoparticles have been utilized for constructing electrochemical sensors and biosensors, and these nanoparticles play diverse roles in different sensing systems. The significant functions provided by nanoparticles comprise the immobilization of biomolecules, the catalysis of electrochemical reactions, the improvement of electron transfer among electrode surfaces and proteins, labelling of biomolecules, and still acting as reactant. The exclusive chemical and physical properties of nanoparticles make them enormously appropriate for designing new and enhanced sensing devices, particularly electrochemical sensors and biosensors. The gold nanoparticles are most frequently used for the immobilization of proteins [82]. Xiao et al. [83] initially attached gold nanoparticles to gold electrodes modified with cysteamine monolayer, and then effectively immobilized horseradish peroxidase on these nanoparticles. An additional type of biomolecules, DNA, can also be immobilized with nanoparticles, and used for the creation of electrochemical DNA sensors. In command to immobilize DNA onto the surfaces of nanoparticles, the DNA strands are frequently modified with meticulous functional groups that can work together powerfully with convinced nanoparticles [84].

\section{Nanoparticles in medicine and healthcare}

Nanoparticles have been utilised newly to develop the present imaging techniques for in vivo diagnosis of biomedical disorders. Presently, Iron oxide nanoparticles are being used in patients for both diagnosis and therapy, leading to more effective medication with less unfavourable effects [85]. An exclusive, susceptible and greatly explicit immunoassay system based on the aggregation of gold nanoparticles that are coated with protein antigens, in the attendance of their corresponding antibodies, was also developed [86].

Nanoparticles, as drug delivery systems, are capable to uplift the several crucial properties of free drugs, such as solubility, in vivo stability, pharmacokinetics, biodistribution and enhancing their efficiency [87]. In this facet, nanoparticles could be used as potential drug delivery systems, owing to their advantageous characteristics. As an illustration of cellular delivery, mixed monolayer protected gold clusters were oppressed for in vitro delivery of a hydrophobic

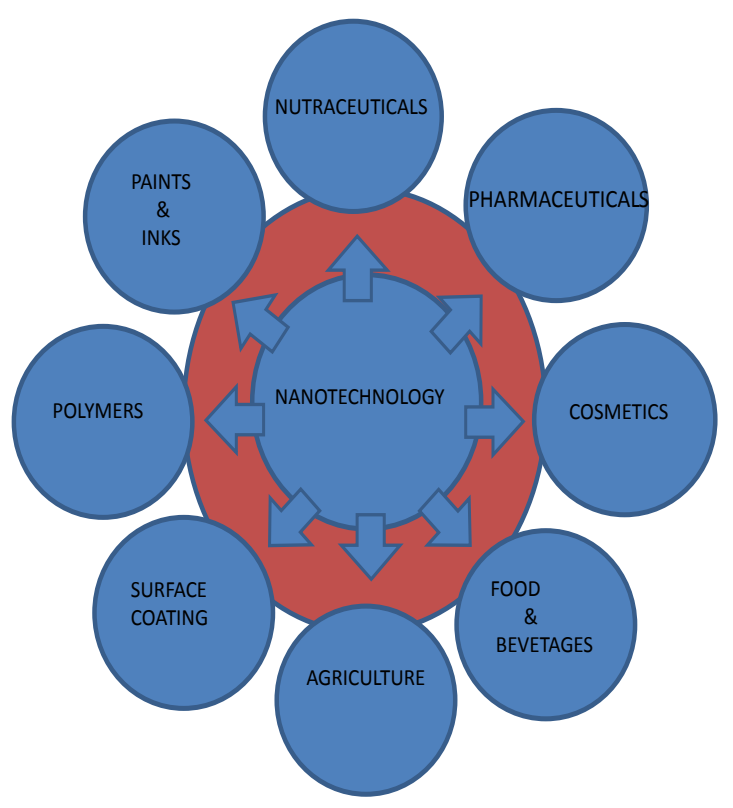

Figure 4: Widespread application of nanotechnology. 
fluorophore [88]. Pandey and Khuller [89] designed nanoparticle for the growth of oral drug delivery system, and recommended that nano-encapsulation may be useful for developing an appropriate oral dosage form for streptomycin, and for other antibiotics that are, if not injectable [89]. Elechiguerra et al. [90] demonstrated the interaction of metal nanoparticles with viruses and explained that silver nanoparticles experience a size-dependent interaction with HIV-1; the nanoparticles of 1-10 nm close to the virus. The usual spatial understanding of the attached nanoparticles, the centre-to-centre space among nanoparticles and the bare sulfur-bearing residues of the glycoprotein knobs suggested that, through favoured binding, the silver nanoparticles prohibited the HIV-1 virus from binding to host cells. Currently, the majority imaging studies using gold nanoparticles are carried out in cell culture [90]. The functional cellular imaging about single molecules has been reported by Peleg et al. [91], captivating benefit of the enhanced second harmonic signal by antibody conjugated gold nanospheres.

The exploitation of nanoparticles in cosmetics and medicine coating is widely increased day by day. The metal oxides in nanoparticle such as zinc oxide and titanium dioxide now emerge on the component records of household products, as general and assorted as cosmetics, sunscreens, toothpaste, and medicine [92].

\section{Nanoparticles in agriculture}

Nanotech delivery systems for pests, nutrients and plant hormones: In the proficient use of agricultural natural assets like water, nutrients and chemicals during precision farming, nanosensors and nano-based smart delivery systems are user friendly. It makes the use of nanomaterials and global positioning systems with satellite imaging of fields, farm supervisors might distantly detect crop pests or facts of stress such as drought. Nanosensors disseminated in the field are able to sense the existence of plant viruses and the level of soil nutrients. To put aside fertilizer consumption and to minimize environmental pollution, nanoencapsulated slow release fertilizers have also become a style [93].

To check the quality of agricultural manufacture, nanobarcodes and nanoprocessing could be used. Li et al. [94] used the idea of grocery barcodes for economical, proficient, rapid and effortless decoding and recognition of diseases. They created microscopic probes or nanobarcodes that may perhaps tag multiple pathogens in a farm, which may simply be detected using any fluorescent-based tools [94].

All the way through nanotechnology, scientists are capable to study plant's regulation of hormones such as auxin, which is accountable for root growth and seedling organization. Nanosensors have been developed that reacts with auxin. This is a step forward in auxin research, as it helps scientists know how plant roots acclimatize to their environment, particularly to marginal soils [95].

Nanotechnology for crop biotechnology: Nanocapsules can facilitate successful incursion of herbicides through cuticles and tissues, allowing slow and regular discharge of the active substances. This can be act as 'magic bullets', containing herbicides, chemicals or genes which target exacting plant parts to liberate their substance [96].

Torney et al. [97] has exploited a $3 \mathrm{~nm}$ mesoporous silica nanoparticle in delivering DNA and chemicals into isolated plant cells. Mesoporous silica nanoparticle are chemically coated and act as containers for the genes delivered into the plants, and triggers the plant to take the particles through the cell walls, where the genes are put in and activated in a clear-cut and controlled way, without any toxic side effects. This technique firstly has been applied to establish DNA fruitfully to tobacco and corn plants [97].

\section{Conclusions}

Nanoparticles present an extremely gorgeous platform for a diverse range of biological applications. As it provides the single step process for biosynthesis of nanoparticles attracts more researchers to go for future developments in the area of electrochemical sensor, biosensors, medicine, healthcare and agriculture.

In this review, we express nanoparticles synthesis using biological methods. These methods are environment friendly and commercially economic. Relationship of special synthesis methods, namely physical, chemical and Biological methods generous highlighting to biogenic synthesis is documented here. Further progresses are desirable in order to revolve the impression of nanoparticle technology into a rational practical approach.

\section{References}

1. Feynman R (1991) There's plenty of room at the bottom. Science 29: 13001301.

2. Murray CB, Kagan CR, Bawendi MG (2000) Synthesis and characterisation of monodisperse nanocrystals and close-packed nanocrystal assemblies. Annu Rev Mater Res 30: 545-610.

3. Ferrari M (2005) Cancer nanotechnology: opportunities and challenges. Nat Rev Cancer 5: 161-171.

4. Chen H, Roco MC, Li X, Lin Y (2008) Trends in nanotechnology patents. Nat Nanotechnol 3: 123-125

5. Li Y, Duan X, Qian Y, Yang L, Liao H (1999) Nanocrystalline silver particles: synthesis, agglomeration, and sputtering induced by electron beam. J Colloid Interface Sci 209: 347-349.

6. Raveendran P, Fu J, Wallen SL (2003) Completely "green" synthesis and stabilization of metal nanoparticles. J Am Chem Soc 125: 13940-13941.

7. Gao X, Cui Y, Levenson RM, Chung LW, Nie S (2004) In vivo cancer targeting and imaging with semiconductor quantum dots. Nat Biotechnol 22: 969-976.

8. Vauthier C, Beanabbou S, Spenlehauer G, Veillard M, Couvreur P (1991) Methodology of ultradispersed polymer system. S T P Pharm Sci 1: 109-116.

9. Alonso MJ (1996) Nanoparticulate drug carrier technology. In: S. Cohen, H Bernstein (Eds.), Microparticulate systems for the delivery of proteins and vaccines. Marcel Dekker, New York, USA 203-242.

10. Sauto EB, Severino P, Santana MHA (2012) Preparation of polymeric nanoparticles by polymerization of monomers-Part I. Polímeros 22: 96-100.

11. Calvo P, Remunan-Lopez C, Vila-Jato JL, Alonso MJ (1997) Novel hydrophilic chitosan-polyethylene oxide nanoprticles as protein carriers. J Appl Polym Sci 63: $125-132$

12. Kreuter J (1994) Nanoparticles. In: Colloidal drug delivery systems. J K Ed Marcel Dekker, New York, USA 219-342.

13. Abou El-Nour KMM, Eftaiha A, Al-Warthan A, Ammar RAA (2010) Synthesis and applications of silver nanoparticles. Arabian Journal of Chemistry 3: 135140.

14. Vithiya K, Sen S (2011) Biosynthesis of nanoparticles. Int J Pharm Sci Res 2 2781-2785.

15. Gurav A, Kodas T, Wang L, Kauppinen E, Joutsensaari J (1994) Generation of nano-meter size fullerene particles via aerosol routes. Chem Phys Lett 218 304-308.

16. Magnusson MH, Deppert K, Malm JO, Bovin JO, Samuelson L (1999) Gold nanoparticles: production, reshaping, and thermal charging. J Nanopart Res 1: 243-251.

17. Kruis FE, Fissan H, Rellinghaus B (2000) Sintering and evaporation characteristics of gas-phase synthesis of size-selected $\mathrm{PbS}$ nanoparticles. Mater Sci Eng B 69: 329-334.

18. Schmidt-Ott A (1988) New approaches to in-situ characterization of ultrafine agglomerates. J Aerosol Sci 5: 553-563. 
Citation: Ingale AG, Chaudhari AN (2013) Biogenic Synthesis of Nanoparticles and Potential Applications: An Eco-Friendly Approach. J Nanomed Nanotechol 4: 165. doi:10.4172/2157-7439.1000165

19. Grabar KC, Freeman RG, Hommer MB, Natan MJ (1995) Preparation and characterization of Au colloid monolayers. Anal Chem 67: 735-743.

20. Mirza AZ, Shamshad H (2011) Preparation and characterization of doxorubicin functionalized gold nanoparticles. Eur J Med Chem 46: 1857-1860.

21. Shankar SS, Rai A, Ahmad A, Sastry M (2004) Biosynthesis of silver and gold nanoparticles from extracts of different parts of the Geranium plant. Applications in Nanotechnology 1: 69-77.

22. Chandran SP, Chaudhary M, Pasricha R, Ahmad A, Sastry M (2006) Synthesis of gold nanotriangles and silver nanoparticles using Aloe vera plant extract. Biotechnol Prog 22: 577-583.

23. Huang J, Li Q, Sun D, Lu Y, Su Y, et al. (2007) Biosynthesis of silver and gold nanoparticles by novel sundried Cinnamomum camphora leaf. Nanotechnology 18: $11-15$.

24. Shankar SS, Rai A, Ahmad A, Sastry M (2004) Rapid synthesis of Au, Ag, and bimetallic Au core-Ag shell nanoparticles using Neem (Azadirachta indica) leaf broth. J Colloid Interface Sci 275: 496-502.

25. Patil CD, Patil SV, Borase HP, Salunke BK, Salunkhe RB (2012) Larvicidal avtivity of silver nanoparticles synthesised using Plumeria rubra plant latex against Aedes aegypti and Anopheles stephensi. Parasitol Res 110: 18151822.

26. Singh AK, Talat M, Singh DP, Srivastava ON (2010) Biosynthesis of gold and silver nanoparticles by natural precursor clove and their functionalization with amine. J Nanopart Res 12: 1667-1675.

27. Christensen L, Vivekanandhan S, Misra M, Mohanty A (2011) Biosynthesis of silver nanoparticles using murraya koenigii (curry leaf): An investigation on the effect bof broth concentration in reduction mechanism and particle size. Adv Mat Lett 2: 429-434.

28. Vankar PS, Bajpai D (2010) Preparation of gold nanoparticles from Mirabilis jalapa flowers. Indian J Biochem Biophys 47: 157-160.

29. Kalpana Devi V, Sumathi R, Varalakshmi P (1994) Evaluation of the antidotal effect of DL-?-lipoic acid against mercuric chloride induced acute renal dysfunction. Med Sci Res 22: 859-862.

30. Pala R, Pathipati UR, Bojja S (2010) Qualitative assessment of silver and gold nanoparticle synthesis in various plants: A photobiological approach. J Nanopart Res 12: 1711-1721.

31. Daizy P (2010) Green synthesis of gold and silver nanoparticles using Hibiscus rosa sinensis. Physica E 42: 1417-1424

32. Ganesh Babu MM, Gunasekaran P (2009) Production and structura characterization of crystalline silver nanoparticles from Bacillus cereus isolate. Colloids Surf B Biointerfaces 74: 191-195.

33. Jain D, Kachhwaha S, Jain R, Srivastava G, Kothari SL (2010) Novel microbia route to synthesize silver nanoparticles using spore crystal mixture of Bacillus thuringiensis. Indian J Exp Biol 48: 1152-1156.

34. Gurunathan S, Kalishwaralal K, Vaidyanathan R, Venkataraman D, Pandian SR, et al. (2009) Biosynthesis, purification and characterization of silver nanoparticles using Escherichia coli. Colloids Surf B Biointerfaces 74: 328-335.

35. Sweeney RY, Mao C, Gao X, Burt JL, Belcher AM, et al. (2004) Bacterial biosynthesis of cadmium sulfide nanocrystals. Chem Biol 11: 1553-1559.

36. Sintubin L, De Windt W, Dick J, Mast J, van der Ha D, et al. (2009) Lactic acid bacteria as reducing and capping agent for the fast and efficient production of silver nanoparticles. Appl Microbiol Biotechnol 84: 741-749.

37. Klaus T, Joerger R, Olsson E, Granqvist CG (1999) Silver-based crystalline nanoparticles, microbially fabricated. Proc Natl Acad Sci U S A 96: 1361113614.

38. Zhang H, Li Q, Lu Y, Sun D, Lin X, et al. (2005) Biosorption and bioreduction of diamine silver complex by Corynebacterium. J Chem Technol Biotechnol 80:285-290.

39. Nanda A, Saravanan M (2009) Biosynthesis of silver nanoparticles from Staphylococcus aureus and its antimicrobial activity against MRSA and MRSE. Nanomedicine 5: 452-456.

40. Juibari MM, Abbasalizadeh S, Jouzani GS, Noruzi M (2011) Intensified biosynthesis of silver nanoparticles using a native extremophilic Ureibacillus thermosphaericus strain. Mater Lett 65: 1014-1017.
41. Gade AK, Bonde P, Ingle AP, Marcato PD, Durän N, et al. (2008) Exploitation of Aspergillus niger for synthesis of silver nanoparticles. Journal of Biobased Materials and Bioenergy 2: 243-247.

42. Binupriya AR, Sathishkumar M, Yun SI (2010) Myco-crystallization of silver ions to nanosized particles by live and dead cell filtrates of Aspergillus oryzae var. viridis and its bactericidal activity toward Staphylococcus aureus KCCM 12256. Ind Eng Chem Res 49: 852-858.

43. Duran N, Marcato PD, De Souza GIH, Alves OL, Esposito E (2007) Antibacteria effect of silver nanoparticles produced by fungal process on textile fabrics and their effluent treatment. J Biomed Nanotechnol 3: 203-208.

44. Ingle A, Rai M, Gade A, Bawaskar M (2009) Fusarium solani: A novel biological agent for the extracellular synthesis of silver nanoparticles. J Nanopart Res 11 : 2079-2085.

45. Nithya R, Ragunathan R (2009) Synthesis of silver nanoparticles using Pleurotus sajor caju and its antimicrobial study. Digest Journal of Nanomaterials and Biostructures 4: 623-629.

46. Thakkar KN, Mhatre SS, Parikh RY (2010) Biological synthesis of metallic nanoparticles. Nanomedicine 6: 257-262.

47. Fesharakil PJ, Nazaril P, Shakibaiel M, Rezaiell S, Banoee M, et al. (2010) Biosynthesis of selenium nanoparticles using Klebsiella pneumoniae and their recovery by a simple sterilization process. Braz J Microbiol 41: 461-466.

48. Kowshik M, Ashtaputre S, Kharrazi S, Vogel W, Urban J, et al. (2003) Extracellular synthesis of silver nanoparticles by a silver-tolerant yeast strain MKY3. Nanotechnology 14: 95-100.

49. Dameron CT, Reese RN, Mehra RK, Kortan AR, Carroll PJ, et al. (1989) Biosynthesis of cadmium sulphide quantum semiconductor crystallites. Nature 338:596-597.

50. Mourato A, Gadanho M, Lino AR, Tenreiro R (2011) Biosynthesis of crystalline silver and gold nanoparticles by extremophilic yeasts. Bioinorg Chem Appl 2011: 546074

51. Seshadri S, Saranya K, Kowshik M (2011) Green synthesis of lead sulfide nanoparticles by the lead resistant marine yeast, Rhodosporidium diobovatum. Biotechnol Prog 27: 1464-1469.

52. Mahtab R, Rogers JP, Murphy CJ (1995) Protein-Sized quantum do luminescence can distinguish between straight", "bent", and "kinked" oligonucleotides. J Am Chem Soc 117: 9099-9100.

53. Shaiu WL, Larson DD, Vesenka J, Henderson E (1993) Atomic force microscopy of oriented linear DNA molecules labeled with $5 \mathrm{~nm}$ gold spheres. Nucleic Acids Res 21: 99-103.

54. Safer D, Bolinger L, Leigh JS Jr (1986) Undecagold clusters for site-specific labeling of biological macromolecules: simplified preparation and model applications. J Inorg Biochem 26: 77-91.

55. Hainfeld JF, Furuya FR (1992) A 1.4-nm gold cluster covalently attached to antibodies improves immunolabeling. J Histochem Cytochem 40: 177-184.

56. Shenton W, Davies SA, Mann S (1999) Directed self-assembly of nanoparticles into macroscopic materials using antibody-antigen recognition. Adv Mater 11 449-452.

57. Beesley JE (1989) In: Colloidal Gold: Principles, Methods, and Applications, MA Hayat, ed. Academic Press, New York, USA.

58. Sunkar S, Nachiyar CV (2012) Microbial synthesis and characterization of silver nanoparticles using the endophytic bacterium Bacillus cereus: a novel source in the benign synthesis. Global Journal of Medical Research 12: 43-49.

59. Slawson RM, Lohmeier-Vogel EM, Lee H, Trevors JT (1994) Silver resistance in Pseudomonas stutzeri. Biometals 7: 30-40.

60. Sharma N, Pinnaka AK, Raje M, Fnu A, Bhattacharyya MS, et al. (2012) Exploitation of marine bacteria for production of gold nanoparticles. Microb Cell Fact 11: 86

61. Prasad K, Jha AK, Kulkarni AR (2007) Lactobacillus assisted synthesis of titanium nanoparticles. Nanoscale Res Lett 2: 248-250.

62. Ahmad A, Mukherjee P, Senapati S, Mandal D, Khan MI, et al. (2003) Extracellular biosynthesis of silver nanoparticles using the fungus Fusarium oxysporum. Colloids Surf B Biointerfaces 28: 313-318.

63. Birla SS, Tiwari VV, Gade AK, Ingle AP, Yadav AP, et al. (2009) Fabrication 
Citation: Ingale AG, Chaudhari AN (2013) Biogenic Synthesis of Nanoparticles and Potential Applications: An Eco-Friendly Approach. J Nanomed Nanotechol 4: 165. doi:10.4172/2157-7439.1000165

of silver nanoparticles by Phoma glomerata and its combined effect against Escherichia coli, Pseudomonas aeruginosa and Staphylococcus aureus. Let Appl Microbiol 48: 173-179.

64. Sadowski Z, Maliszewska IH, Grochowalska B, Polowczyk I, Kozlecki T (2008) Synthesis of silver nanoparticles using microorganisms. Materials SciencePoland 26: 419-424.

65. Douglas T, Young M (1998) Host-guest encapsulation of materials by assembled virus protein cages. Nature 393: 152-155.

66. Douglas T, Strable E, Willits D, Aitouchen A, Libera M, et al. (2002) Protein engineering of a viral cage for constrained nanomaterials synthesis. Adv Mater 14: $415-418$

67. Shenton W, Douglas T, Young M, Stubbs G, Mann S (1999) Inorganic-organic nanotube composites from template mineralization of tobacco mosaic virus. Adv Mater 11: 253-256.

68. Mao C, Flynn CE, Hayhurst A, Sweeney R, Qi J, et al. (2003) Viral assembly of oriented quantum dot nanowires. Proc Natl Acad Sci U S A 100: 6946-6951.

69. Choi $\mathrm{Y}$, Ho NH, Tung $\mathrm{CH}$ (2007) Sensing phosphatase activity by using gold nanoparticles. Angew Chem Int Ed Engl 46: 707-709.

70. Yoosaf K, Ipe BI, Suresh CH, Thomas KG (2007) In situ synthesis of metal nanoparticles and selective naked-eye detection of lead ions from aqueous media. J Phys Chem 111: 12839-12847.

71. Hutter E, Fendler JH (2004) Exploitation of localized surface plasmon resonance. Adv Mater 16: 1685-1706.

72. Sun S, Murray CB, Weller D, Folks L, Moser A (2000) Monodisperse FePt nanoparticles and ferromagnetic FePt nanocrystal superlattices. Science 287 1989-1992.

73. Vilchis-Nestor AR, Sanchez-Mendieta V, Camacho-Lopez M, Gomez-Espinosa RM, Camacho-Lopez MA, et al. (2008) Solvent less synthesis and optical properties of $\mathrm{Au}$ and $\mathrm{Ag}$ nanoparticles using Camellia sinensis extract. Mater Lett 62: 3103-3105.

74. Lee HJ, Yeo SY, Jeong SH (2003) Antibacterial effect of nanosized silver colloidal solution on textile fabrics. J Mater Sci 38: 2199-2204.

75. Zhang J, Chen P, Sun C, Hu X (2004) Sonochemical synthesis of colloida silver catalysts for reduction of complexing silver in DTR system. Appl Catal A Gen 266: 49-54.

76. Chimentão RJ, Kirm I, Medina F, Rodríguez X, Cesteros Y, et al. (2004) Different morphologies of silver nanoparticles as catalysts for the selective oxidation of styrene in the gas phase. Chem Commun (Camb) 846-847.

77. He B, Tan J, Liew K, Liu H (2004) Synthesis of size controlled Ag nanoparticles. J Mol Catal A 221: 121-126.

78. Khomutov GB, Gubin SP (2002) Interfacial synthesis of noble metal nanoparticles. Mater Sci Eng C 22: 141-146.

79. Raheman F, Deshmukh S, Ingle A, Gade A, Rai M (2011) Silver nanoparticles: Novel antimicrobial agent synthesized from a endophytic fungus Pestalotia sp. isolated from leaves of Syzygium cumini (L.). Nano Biomed Eng 3: 174-178.
80. Rai MK, Deshmukh SD, Ingle AP, Gade AK (2012) Silver nanoparticles: the powerful nanoweapon against multidrug-resistant bacteria. J Appl Microbio 112: 841-852.

81. Morones JR, Elechiguerra JL, Camacho A, Holt K, Kouri JB, et al. (2005) The bactericidal effect of silver nanoparticles. Nanotechnology 16: 2346-2353.

82. Liu S, Leech D, Ju H (2003) Application of colloidal gold in protein immobilization electron transfer, and biosensing. Anal Lett 36: 1-19.

83. Xiao $\mathrm{Y}$, Ju H, Chen $\mathrm{H}$ (1999) Hydrogen peroxide sensor based on horseradish peroxidase-labeled $\mathrm{Au}$ colloids immobilized on gold electrode surface by cysteamine monolayer. Anal Chim Acta 391: 73-82.

84. Cai H, Xu C, He P, Fang Y (2001) Colloid Au-enhanced DNA immobilization fo the electrochemical detection of sequence-specific DNA. J Electroanal Chem 510: 78-85.

85. Gao L, Zhang D, Chen M (2008) Drug nanocrystals for the formulation of poorly soluble drugs and its application as a potential drug delivery system. $J$ Nanopart Res 10: 845-862.

86. Thanh NT, Rosenzweig Z (2002) Development of an aggregation-based immunoassay for anti-protein A using gold nanoparticles. Anal Chem 74: 16241628

87. Allen TM, Cullis PR (2004) Drug delivery systems: entering the mainstream Science 303: 1818-1822.

88. Hong R, Han G, Fernández JM, Kim BJ, Forbes NS, et al. (2006) Glutathionemediated delivery and release using monolayer protected nanoparticle carriers. J Am Chem Soc 128: 1078-1079.

89. Pandey R, Khuller GK (2007) Nanoparticle-based oral drug delivery system for an injectable antibiotic - streptomycin. Evaluation in a murine tuberculosis model. Chemotherapy 53: 437-441.

90. Elechiguerra JL, Burt JL, Morones JR, Camacho-Bragado A, Gao X, et al (2005) Interaction of silver nanoparticles with HIV-1. J Nanobiotechnology 3: 6

91. Peleg G, Lewis A, Linial M, Loew LM (1999) Nonlinear optical measurement of membrane potential around single molecules at selected cellular sites. Proc Natl Acad Sci U S A 96: 6700-6704.

92. Yu JX, Li TH (2011) Distinct biological effects of different nanoparticles commonly used in cosmetics and medicine coatings. Cell Biosci 1: 19

93. DeRosa MC, Monreal C, Schnitzer M, Walsh R, Sultan Y (2010) Nanotechnology in fertilizers. Nat Nanotechnol 5: 91

94. Li Y, Cu YT, Luo D (2005) Multiplexed detection of pathogen DNA with DNAbased fluorescence nanobarcodes. Nat Biotechnol 23: 885-889.

95. McLamore ES, Diggs A, Calvo Marzal P, Shi J, Blakeslee JJ, et al. (2010) Noninvasive quantification of endogenous root auxin transport using an integrated flux microsensor technique. Plant J 63: 1004-1016.

96. Pérez-de-Luque A, Rubiales D (2009) Nanotechnology for parasitic plan control. Pest Manag Sci 65: 540-545.

97. Torney F, Trewyn BG, Lin VS, Wang K (2007) Mesoporous silica nanoparticles deliver DNA and chemicals into plants. Nat Nanotechnol 2: 295-300. 